\title{
THE RELATIONSHIP BETWEEN RESEARCH AND
}

TEACHING: ASSESSING THE STUDENTS'

PERCEPTIONS IN THE CONTEXT OF A NEW

EVALUATION METHODOLOGY

RELAȚIA CERCETARE - PREDARE: INVESTIGAREA PERCEPȚIILOR STUDENȚILOR ÎN CONTEXTUL UNEI NOI METODOLOGII DE EVALUARE

\section{Miruna - Luana MIULESCU}

\author{
Journal of Pedagogy, 2019 (2), 125 - 137
}

https://doi.org/10.26755/RevPed/2019.2/125

The online version of this article can be found at: http://revped.ise.ro/category/2019-en/

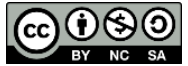

This work is licensed under the Creative Commons Attribution-NonCommercial-ShareAlike 4.0 International License. View, CA 94042, USA.

Published by:

\section{INSTITUTUL DE ȘTIINȚE ALE EDUCAȚIEI}

http://www.ise.ro/

Further information about Revista de Pedagogie - Journal of Pedagogy can be found at:

Editorial Policy: http://revped.ise.ro/editorial-policy/

Author Guidelines: http://revped.ise.ro/the-writer-guide-2/ 


\title{
THE RELATIONSHIP BETWEEN RESEARCH AND TEACHING: ASSESSING THE STUDENTS' PERCEPTIONS IN THE CONTEXT OF A NEW EVALUATION METHODOLOGY
}

\author{
Miruna Luana Miulescu* \\ Institute of Educational Sciences, \\ Bucharest, Romania \\ miruna.miulescu@gmail.com
}

\begin{abstract}
As teaching and research are perceived as two core academic activities, various attempts have been made to incorporate research into the teaching process. Literature suggests that the link between research and teaching does not only improve the students' subject knowledge, but also their critical thinking and problem-solving skills. The present paper focuses on the students' perception of research integration into the teaching process at the undergraduate education level, second year within the Educational Sciences specialization at the University of Bucharest, Faculty of Psychology and Educational Sciences. The aim of the study was to understand the way students perceive the research integration in their courses in the context of introducing a new assessment methodology which focuses on this process. The one-group pre-test - post-test research design involved collecting data from 52 students using the Student Perception of Research Integration Questionnaire (SPRIQ). Data analysis revealed that students perceive many potential benefits when research is integrated into the teaching activity, they are more motivated and interested in the way research is carried out in their department, and have a better perception of their learning environment.
\end{abstract}

Keywords: assessment methodology, research-teaching relationship, Student Perception of Research Integration Questionnaire (SPRIQ).

* Researcher, Institute of Educational Sciences, Bucharest, Romania.

PhD. Candidate, University of Bucharest, Faculty of Psychology and Educational Sciences, Bucharest, Romania. 


\section{Rezumat}

Deoarece predarea şi cercetarea sunt percepute ca două activită $i$ academice de bază, au existat diverse încercări de a încorpora cercetarea în procesul de predare. Literatura de specialitate sugerează că legătura dintre cercetare şi predare nu numai că îmbunătă eşte cunoştin ele studen ilor, ci şi gândirea critică şi abilită ile de rezolvare de probleme. Lucrarea de fa ă se concentrează pe percep ia studen ilor în ceea ce priveşte integrarea cercetării în procesul de predare la nivelul învă ământului universitar, anul II în specializarea Ştiin ele Educa iei la Universitatea din Bucureşti, Facultatea de Psihologie şi Ştiin ele Educa iei. Scopul studiului este de a în elege modul în care studen ii percep integrarea elementelor de cercetare în cursurile lor în contextul introducerii unei noi metodologii de evaluare. Designul de cercetare pre-test - post-test a implicat colectarea datelor de la 52 de studen i folosind Chestionarul de Percep ie a Integrării Cercetării (SPRIQ). Analiza datelor a relevat faptul că studen ii percep mai multe beneficii atunci când cercetarea este integrată în activitatea de predare, sunt mai motiva $i$ şi interesa i de modul în care se desfăşoară cercetarea în departament şi au o percep ie mai bună a mediului lor de învă are.

Cuvinte-cheie: Chestionarul de Percep ie a Integrării Cercetării (SPRIQ), metodologie de evaluare, rela ia cercetare-predare.

\section{Introduction}

Nowadays, an important aspect of the higher education debate on student learning is related to research-integrated teaching. However, the idea of meeting the needs of the student's learning by strengthening the link between research and teaching is still perceived as a challenge. (Neumann, 1994; Spronken-Smith, 2014; Vereijken et al., 2016; Visser-Wijnveen, 2010)

According to Robertson and Bond (2001), academics view university research and teaching in different ways. As Badley (2002) argues, research and teaching relationships could be described as follows: 'a really useful link', 'a scholarly relationship', 'a holy alliance', 'a martial relationship', and 'an impending divorce'. These different viewpoints in which the relationship between the two activities could be currently perceived are based on the different interpretations of the terms teaching and research. 
The attempts to describe the intricate nature of the research - teaching linkage have not been few in numbers. The most well-known typology belongs to Griffiths (2004) and can be described as follows (Jenkins, Healey \& Zetter, 2007):

- Research-led teaching. In this research-teaching relationship, the subject content is important for constructing the curriculum; moreover, the chosen content is directly linked to the disciplinary interest of the academic staff. The focus is on understanding research findings rather than research processes.

- Research-oriented teaching. In this research - teaching relationship, the curriculum is particularly designed around understanding the processes by which knowledge is generated in a specific field of study. The focus is on the teaching of research abilities and on promoting a 'research ethos'.

- Research-based teaching. In this research - teaching relationship, the attention is on activities that are guided by exploration, while the collaboration between the research activity and the teaching one is emphasised.

STUDENT AS

PARTICIPANT

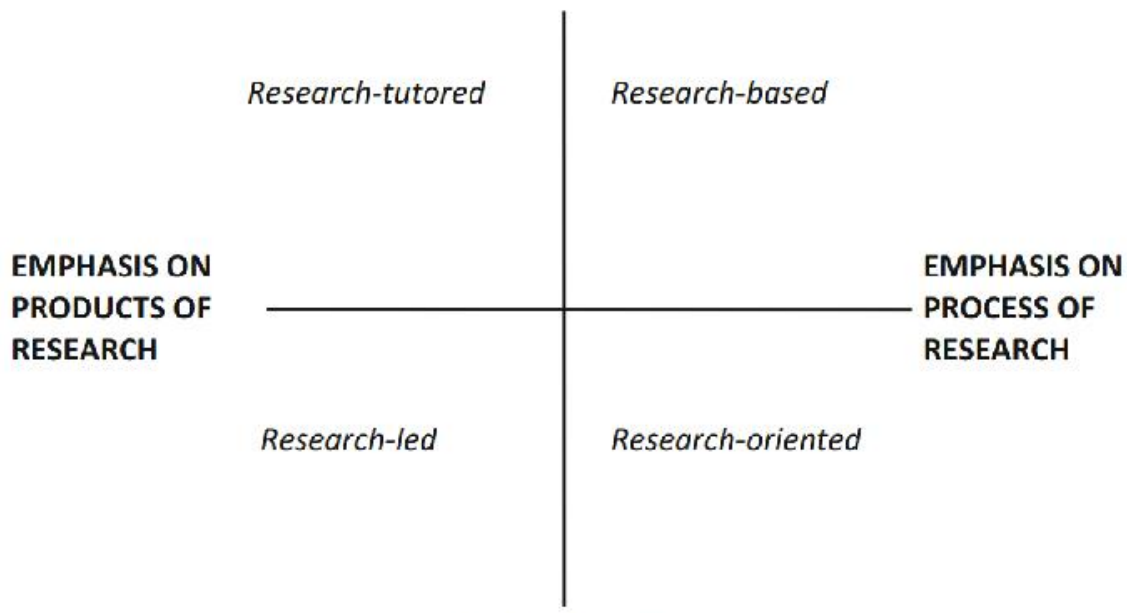

STUDENT AS AUDIENCE

Figure no.1 Modes of the research - teaching relationship (adapted from Healey, 2005) 
- Research-tutored teaching. In this research - teaching relationship, the emphasis is on the systematic exploration of the teaching and learning process itself.

In order to capture the complexity of the relationships that arise between the research and teaching activities from the perspective of university teachers, researchers Visser-Wijnveen, Van Driel, Van der Rijst, Verloop, and Visser (2010) built an empirical basis for Griffiths's (2004) and Healey's (2005) typologies. 30 professors from the Faculty of Humanities at the University of Leiden were interviewed and were asked to describe the ideal connection between research and teaching. The descriptions of the ideal linkage had led the authors to conclude that we could talk about five profiles of the research-teaching connection, namely (Visser-Wijnveen et al., 2010, p. 203):

1. Teach research results - the teaching of research results are transferred by direct communication from teacher to students or by reading the literature on the topic.

2. Make research known - this activity involves the familiarization of students with research.

3. Show what it means to be a researcher-the focus is on research processes and academic dispositions. The researcher relates his/her own experiences and incorporates research practice into the teaching process.

4. Help to conduct research - The teacher is a tutor for the students and his/her main goal is to develop research competencies. Besides assigning them small research tasks, teachers can involve students in different research-related activities.

5. Provide research experience - The teacher takes the role of a guide whose mission is to train the students to become researchers, based on their coaching competencies. Therefore, the students are fully participating in many different activities connected to academic research.

According to Cleaver et al. (2014), a significant step in shaping the characteristics of the current undergraduate education was made by the Boyer Commission in the USA (Boyer, 1998). One particular idea that was highlighted concerned the participation of both academics and students in the production of knowledge. In other words, students should be regarded as valuable individuals who can contribute significantly to the quality of 
the educational processes by engaging in 'discovery-based activities'.

Various attempts have been made to incorporate research into the teaching activity at the university level, as students' perception of teaching appears to be an important factor in fostering student learning. Literature suggests that the linkage between research and teaching not only improves students' subject knowledge, but also their critical thinking and problem-solving skills (Bauer \& Bennett, 2003; Hensel, 2012; Russell Group, 2014; Walkington, 2015). Moreover, Kinkead (2011) contributes to the topic by highlighting the idea that students receive numerous benefits in terms of collaborating with other professionals and/or with their own colleagues.

\section{The research methodology}

\subsection{Research Questions}

The investigative approach was led by the following questions:

1. What are the benefits of a strong relationship between research and teaching?

2. How can research-related elements be integrated into the teaching process?

\subsection{Purpose of the Study}

The purpose of the research was to study the way the integration of researchrelated elements in the context of introducing a new assessment methodology could change the student's perception of the research-teaching relationship.

\subsection{Hypotheses}

General hypothesis: The intervention applied leads to a statistically significant change in the perception of students regarding the integration of research into the teaching activity at the department.

Specific hypotheses: 
1. The applied intervention leads to a statistically significant change in the assessment of current research.

2. The applied intervention leads to a statistically significant change in research beliefs.

3. The applied intervention leads to a statistically significant change in the involvement in research without highlighting the purpose.

4. The applied intervention leads to a statistically significant change in the student appreciation and involvement.

5. The applied intervention leads to a statistically significant change in the assessment of the quality of the course and the involvement of the teachers.

6. The applied intervention leads to a statistically significant change in the interest and motivation regarding the area of specialization.

7. The applied intervention leads to a statistically significant change in the interest and reflection (research attention and awareness).

\subsection{Research Methods}

The research had a one-group pre-test - post-test pre-experimental design in which 52 students from a single group attended the same academic course (i.e., Classroom Management course) and were given the same assessment. As a first step, we distributed the hardcopy questionnaires to all the students in February 2019, during the first lecture of the Classroom Management course. Throughout the semester the students were told that the final course assessment involved a proposal of three research topics based on some predetermined themes which were related to the course specificities (a process which involved selecting and reading scientific studies), identifying five benefits that research can bring for the teaching practice and preparing an essay based on their own reflections upon the advantages and disadvantages on research integration after getting familiarized with research findings and processes. The second measurement took place in June 2019 after the assessment period, when the same questionnaire was distributed.

In order to study the perception of research integration in the context of a new assessment methodology, 52 students in their $2^{\text {nd }}$ year of the Bachelor programme in Educational Sciences (University of Bucharest, Faculty of 
Psychology and Educational Sciences) participated in the study. For this purpose, we administered the Student Perception of Research Integration Questionnaire (SPRIQ), which was developed and validated in 2015 by researchers Visser-Wijnveen, van der Rijst and van Driel. Its scales include student perceptions of teaching through (1) critical reflection on the way research results are produced; (2) research participation as a student; (3) familiarity with current research conducted by staff; (4) fostering interest and motivation for research and propositions to measure (5) students' beliefs about the value of research for learning and (6) perceived quality of the learning environment.

Since the SPRIQ has been validated for the medicine, sciences, and humanities we slightly adjusted items to fit the educational sciences context. All 40 items were answered on a 5-point Likert-scale.

\section{Results}

In the first stage, the method of extraction used in order to identify possible overlaps was the Principal Components Method. Moreover, the Varimax method with Kaiser normalization was the rotation method of the factors chosen for this approach. The analysis included the 40 items included in the questionnaire developed by the researchers. The KMO index recorded a value between the accepted thresholds, which can be characterized as an excellent index of the degree of adequacy for the exploratory factor analysis $(\mathrm{KMO}=.958)$. Also, the value of the Bartlett index $(\mathrm{p}<.001)$ is significant and shows that the measured variables are correlated, indicating the presence of one or more common factors.

Table no. 1. KMO and Bartlett multicollinearity tests for SPRIQ questionnaire items

\begin{tabular}{|c|c|c|}
\hline \multicolumn{2}{|c|}{ Kaiser-Meyer-Olkin Measure of Sampling Adequacy. } & .958 \\
\hline \multirow[t]{3}{*}{ Bartlett's Test of Sphericity } & Approx. Chi-Square & 14690.838 \\
\hline & df & 780 \\
\hline & $\mathrm{P}$. & .000 \\
\hline
\end{tabular}


Following the Rotated Component Matrix analysis, it is found that, compared to the original form, which has a number of 10 subscales and 6 final scales, the items load 7 dimensions of the research-teaching integration: (1) current research; (2) research beliefs; (3) involvement in research without highlighting the purpose; (4) student appreciation and involvement; (5) the quality of the course and the involvement of the teachers; (6) interest and motivation regarding the area of specialization; (7) interest and reflection (research attention and awareness).

The exploratory factorial analysis demonstrates that the distribution of each item within the dimensions is similar to that of the 2015 study. The factorial structure and internal consistency were tested for each of the 7 dimensions. In terms of internal consistency analysis, a high Cronbach Alpha coefficient was obtained both globally, on the level of the SPRIQ questionnaire (.968), as well as for the 7 dimensions.

Table no. 2. Cronbach Alpha's internal consistency coefficient for Student Integration Research Questionnaire (SPRIQ)

\begin{tabular}{|c|c|c|}
\hline Cronbach's Alpha & $\begin{array}{l}\text { Cronbach's Alpha } \\
\text { Based on } \\
\text { Standardized } \\
\text { Items }\end{array}$ & $\mathrm{N}$ of Items \\
\hline .968 & .968 & 40 \\
\hline
\end{tabular}

The aim of this study was to investigate the effectiveness of the introduction of a new assessment methodology which placed emphasis on the research activity. Thus, data was collected from pre-test and post-test and descriptive analysis was performed in order to determine the mean and the standard deviation.

Table no. 3 below shows the paired samples statistics of the seven dimensions' pre-test and post-test results. Pre-test of the current research dimension with the mean value of 37.56 indicated that students are familiar 
with the teacher's research and are interested in finding out more about research in general. On the other hand, the lowest pre-test mean is 14.51 which is reflected in the dimension concerning students' appreciation and involvement in the research activities aspects that may imply that students are not very involved in the scientific research and their contribution is not appreciated.

Table no. 3. The Paired Samples Statistics of seven dimensions

\begin{tabular}{|l|c|c|c|c|}
\hline \multicolumn{1}{|c|}{ Dimensions } & \multicolumn{2}{c|}{ Pre-Test } & \multicolumn{2}{c|}{ Post-Test } \\
\hline Current research & 37.56 & 9.68 & 41.55 & 7.00 \\
\hline Research beliefs & 14.75 & 3.74 & 15.11 & 2.92 \\
\hline $\begin{array}{l}\text { Deviation } \\
\text { Deviation }\end{array}$ \\
\hline \begin{tabular}{l} 
research \\
\hline $\begin{array}{l}\text { Student } \\
\text { appreciation and } \\
\text { involvement }\end{array}$
\end{tabular} & 19.24 & 5.03 & 19.89 & 4.68 \\
\hline $\begin{array}{l}\text { Course quality } \\
\text { course \& teacher } \\
\text { involvement }\end{array}$ & 15.66 & 3.84 & 16.91 & 2.87 \\
\hline $\begin{array}{l}\text { Interest and } \\
\text { motivation }\end{array}$ & 17.61 & 3.86 & 19.36 & 2.55 \\
\hline $\begin{array}{l}\text { Interest and } \\
\text { reflection }\end{array}$ & 21.80 & 4.62 & 24.13 & 3.22 \\
\hline
\end{tabular}

Table no. 4 shows the results of the paired t-test for all seven dimensions. Thus, it can be concluded that is a statistically significant difference between mean ratings of the pre-test and post-test for each dimension. Nevertheless, in the case of the research beliefs dimension, the statistical analysis showed that the 5\% significance level was not achieved. Therefore, the specific hypothesis regarding the research beliefs was rejected. 
Table no. 4. The Paired Samples Statistics of seven dimensions

\begin{tabular}{|l|c|c|c|}
\hline \multicolumn{1}{|c|}{$\begin{array}{c}\text { Paired sample } \\
\text { (Post - Pre) }\end{array}$} & \multicolumn{2}{|c|}{ Paired Differences (\%) } & Sig. (2-tailed) \\
\hline Current research & Mean & $\begin{array}{c}\text { Standard } \\
\text { Deviation }\end{array}$ & \\
\hline Research beliefs & 3.98 & 3.36 & .000 \\
\hline Involvement in research & .36 & 1.50 & .064 \\
\hline $\begin{array}{l}\text { Student appreciation and } \\
\text { involvement }\end{array}$ & 1.33 & 1.56 & .004 \\
\hline $\begin{array}{l}\text { Course quality course \& } \\
\text { teacher involvement }\end{array}$ & 1.25 & 1.56 & .000 \\
\hline Interest and motivation & 1.75 & 1.71 & .000 \\
\hline Interest and reflection & 2.33 & 2.25 & .000 \\
\hline
\end{tabular}

\section{Conclusions}

The results of the study showed that the assessment methodology has positive impact in enhancing the students' perception regarding the current research, the involvement in research without highlighting the purpose, the students' appreciation and involvement, the quality of the course and the teachers' involvement, the interest and motivation concerning the area of specialization, and interest and reflection (research attention and awareness). Moreover, the paired t-test concluded that there is a statistically significant difference between mean ratings in the pre and post-tests for almost all seven dimensions with the exception of the one regarding the research beliefs.

Previous studies (Verburgh \& Elen, 2011) emphasise that students' beliefs about academic research can be best promoted by integrating research elements into teaching within courses. At the same time, Pajares (1992) points out that by the time students enter the university their beliefs are well established and that the process of changing them is difficult and involves a lot of effort from the teacher's part. Also, it should be also taken 
into consideration that students may have had prior experiences with research integration into teaching which could have greatly shaped the individual characteristics they brought into the university classroom (Prosser \& Trigwell, 2014). If we consider all these issues, there is no surprise that of all dimensions, beliefs about the value of research showed no statistically significant difference between the pre and post-test ratings.

Although there are important limitations to the causal conclusions drawn from these results, our data suggests the following implications for practice. Firstly, the statistical analysis may serve as a proof that developing an assessment methodology which is fundamentally concentrated on encouraging academic research can be an effective way in strengthening the students' perception on the integration of research into teaching. Secondly, the intervention not only improved the students' perception on participating in research activities and getting familiarised with current research done by academic staff but also on the quality of the learning environment, and fostering their motivation and interest for research.

The results from this study are intended to inspire and inform teachers, academic managers and policy makers to strengthen the relationship between academic research and teaching at the university level. Moreover, this study will help teachers reflect upon ways of encouraging the link between research and teaching without neglecting to describe the contribution of this relationship to student learning and academic achievement.

\section{References}

- Badley, G. (2002). A really useful link between teaching and research. Teaching in Higher Education, 7(4), 443-455. https://doi.org/10.1080/ 135625102760553937

- Bauer, K. W., \& Bennett, J. S. (2003). Alumni Perceptions Used to Assess Undergraduate Research Experience. The Journal of Higher Education, 74(2), 210-230. https://doi.org/10.1080/00221546.2003.11777197

- Boyer Commission on Educating Undergraduates in the Research University (1998). Reinventing undergraduate education: a blueprint for America's research universities. New York, USA: State University of New York-Stony Brook. 
- Cleaver, E., Lintern, M., \& McLinden, M. (2014). Teaching and Learning in Higher Education: Disciplinary Approaches to Educational Enquiry. London, UK: Sage.

- Griffiths, R. (2004). Knowledge production and the research-teaching nexus: The case of the built environment disciplines. Studies in Higher Education, 29(6), 709-726.

- Hensel, N. (Ed.). (2012). Characteristics of Excellence in Undergraduate Research. Washington, DC: The Council on Undergraduate Research (CUR). Retrieved from http://www.cur.org/assets/1/23/COEUR_final.pdf

- Jenkins, A., Healey, M., \& Zetter, R. (2007). Linking Research and Teaching in Disciplines and Departments. York: Higher Education Academy.

- Kinkead, J. (2011). Undergraduate Researchers as Makers of Knowledge in Composition in the Writing Studies Major. In R. Gebhardt \& L. Massey (Eds.), The Changing of Knowledge in Composition: Contemporary Perspectives (pp. 137-160). Logan: Utah State UP.

- Neumann, R. (1994). The Teaching-Research Nexus: Applying a Framework to University Students' Learning Experiences. European Journal of Education, 29(3), 323-338. https://doi.org/10.2307/1503744

- Pajares, M. (1992). Teachers' beliefs and educational research: Cleaning up a messy construct. Review of Educational Research, 62, 307-322. https://doi.org/ 10.3102/00346543062003307

- Prosser, M., \& Trigwell, K. (2014). Qualitative variation in approaches to university teaching and learning in large first-year classes. Higher Education, 67, 783-795. https://doi.org/10.1007/s10734-013-9690-0

- Robertson, J., \& Bond, C. (2001). Experiences of the relation between teaching and research: what do academics value?. Higher Education Research and Development, 20(1), 5-19. https://doi.org/10.1080/07924360120043612

- Russell Group (2014). A Passion for Learning. The Student Experience at Russell Group Universities. UK: The Russell Group. Retrieved from http:// www.russellgroup.ac.uk/media/5037/studentexperienceatrussellgroup universities.pdf

- Spronken-Smith, R., Mirosa, R., \& Darrou, M. (2014). Learning is an endless journey for anyone: Undergraduate awareness, experiences and perceptions of the research culture in a research intensive university. Higher Education Research and Development, 33(2), 355-371. https://doi.org/10.1080/07294360.2013.832169

- Verburgh, A. L., \& Elen, J. (2011). The role of experienced research integration into teaching upon students' appreciation of research aspects in the learning environment. International Journal of University Teaching and Faculty Development, 1(4), 1-14.

- Vereijken, M. W. C., van der Rijst, R.M., de Beaufort, A.J., van Driel. J.H., \& Dekker. F.W. (2016). Fostering first-year student learning through research 
integration into teaching: Student perceptions, beliefs about the value of research and student achievement. Innovations in Education and Teaching International, 55(4), 425-432. https://doi.org/10.1080/14703297.2016.1260490

- Visser-Wijnveen, G., van Driel, J. H., van der Rijst, R. M., Verloop, N., \& Visser, A. (2010). The ideal research-teaching nexus in the eyes of academics: Building profiles. Higher Education Research \& Development, 29, 195-210. https://doi.org/10.1080/07294360903532016

- Walkington, H. (2015). Students as researchers: Supporting undergraduate research in the disciplines in higher education. York: The Higher Education Academy. Retrieved from https://www.heacademy.ac.uk/system/files/resources/ Students\%20as\%20researchers_1.pdf

The online version of this article can be found at: http://revped.ise.ro/category/2019-en/

\section{(c) $)$ BY-NC-SA}

This work is licensed under the Creative Commons Attribution-NonCommercial-ShareAlike 4.0 International License.

To view a copy of this license, visit http://creativecommons.org/licenses/by-nc-sa/4.0/ or send a letter to Creative Commons, PO Box 1866, Mountain View, CA 94042, USA.
Versiunea online a acestui articol poate fi găsită la: http://revped.ise.ro/category/2019-ro/

\section{(cc) BY-NC-sA}

Această lucrare este licen iată sub Creative Commons Attribution-NonCommercial-ShareAlike 4.0 International License.

Pentru a vedea o copie a acestei licen e, vizita $i$ http://creativecommons.org/licenses/by-nc-sa/4.0/ sau trimite i o scrisoare către Creative Commons, PO Box 1866, Mountain View, CA 94042, SUA. 